\title{
The Influence of Intranasal Insulin on Hypothalamic- Pituitary-Thyroid Axis in Normal and Diabetic Rats
}

Authors

Affiliations

\author{
K. V. Derkach ${ }^{1}$, I. V. Bogush ${ }^{1}$, L. M. Berstein ${ }^{2}$, A. O. Shpakov ${ }^{1}$
}

${ }^{1}$ Sechenov Institute of Evolutionary Physiology and Biochemistry, Russian Academy of Sciences, St. Petersburg, Russia ${ }^{2}$ Laboratory of Oncoendocrinology; N.N. Petrov Research Institute of Oncology, St. Petersburg, Russia

\author{
Key words \\ - diabetes mellitus \\ - intranasal insulin \\ - thyroid \\ thyroid-stimulating \\ hormone
}

received $\quad 02.12 .2014$ accepted 11.02.2015

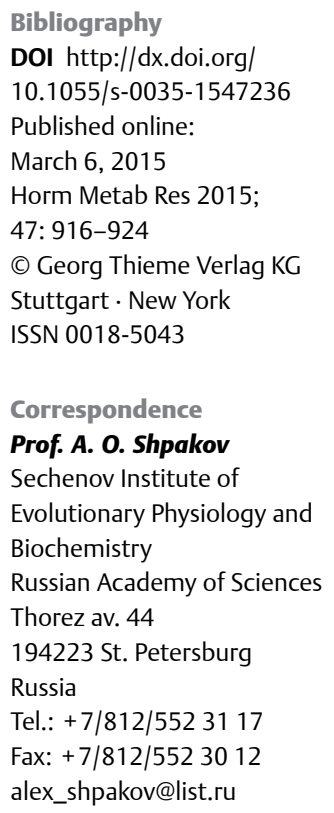

\begin{abstract}
$\checkmark$

The functions of hypothalamic-pituitary-thyroid axis are attenuated in type 1 diabetes mellitus due to insulin deficiency. The use of intranasally administered insulin is of considerable interest for treatment of diabetes and cognitive disorders, but its effect on the thyroid system has not been investigated yet. We studied the influence of long-term treatment with intranasal insulin on the hypothalamic-pituitary-thyroid axis of nondiabetic rats and diabetic animals with streptozotocin models of acute and mild type 1 diabetes mellitus. This treatment was carried out for 28 days in acute (daily does of $0.3,0.6$, and $1.5 \mathrm{IU}$ of insulin per rat) and for 135 days in mild diabetes (daily dose of $0.45 \mathrm{IU} / \mathrm{rat}$ ). Nondiabetic rats were treated in a similar manner. Intranasal insulin in both models of diabetes resulted in
\end{abstract}

\begin{tabular}{ll}
\hline Abbreviations \\
$\nabla$ \\
CNS & Central nervous system \\
DM & Diabetes mellitus \\
DM1 & Type 1 diabetes mellitus \\
HPT axis & Hypothalamic-pituitary-thyroid axis \\
I-I & Intranasal insulin \\
STZ & Streptozotocin \\
TSH & Thyroid-stimulating hormone \\
TRH & Thyrotropin-releasing hormone \\
$\mathrm{T}_{4}$ & Thyroxine \\
$\mathrm{T}_{3}$ & Triiodothyronine
\end{tabular}

\section{Introduction}

$\nabla$

The hypothalamic-pituitary-thyroid (HPT) axis and its main components - thyroid-stimulating hormone (TSH), thyrotropin-releasing hormone (TRH), thyroid hormones, and respective receptors - are responsible for the regulation of cell differentiation, growth, and metabolism in dif- the improvement of thyroid status; manifested as increase of thyroid hormones levels and restoration of response to thyroliberin. In acute diabetes, a daily dose of $0.6 \mathrm{IU} / \mathrm{rat}$ was the most effective. Twenty eight days treatment of nondiabetic rats with intranasal insulin at a dose of $0.3 \mathrm{IU} /$ rat resulted in a significant increase of free and total thyroxine levels. Longer treatment of rats with mild diabetes and nondiabetic animals significantly increased thyrotropin level. Thus, long-term intranasal insulin treatment restored the hypothalamic-pituitary-thyroid axis function in type 1 diabetes, but led to a significant increase in the thyrotropin level, which must be considered when designing a strategy for the use of intranasal insulin in clinical applications.

Supporting Information for this article is available online at http://www.thieme-connect.de/products

ferent areas of the central nervous system (CNS) and in the peripheral tissues of vertebrates [1]. Functional activity of HPT axis is regulated by several feedback mechanisms including thyroid hormones, neurotransmitters, stress-responsive elements, and circadian rhythms [2].

Pathological changes in HPT axis and impairment of its regulation can lead to several thyroid diseases, cardiovascular, and neurological disorders [3-5]. Thyroid dysfunctions can manifest as complications of some diseases, including type 1 diabetes mellitus (DM1) [6-8]. First data showing that thyroid diseases are much more common in patients with DM1 were obtained in the early 1980s $[9,10]$. Later, it was shown that about one third of patients with DM1 have autoimmune thyroid diseases, such as Graves' disease, Hashimoto's thyroiditis, and pospartum thyroiditis $[6,8]$.

Historically, the functional link between DM1 and dysfunctions of HPT axis and the thyroid gland was studied giving preference to experi- 
mental models of DM1 [11-15]. Most of these studies were carried out using the model of acute DM1 induced by a high dose $(55-75 \mathrm{mg} / \mathrm{kg}$ ) of streptozotocin (STZ) [11-14]. Characteristics of this model are absolute insulin deficiency and strong hyperglycemia, which leads to a severe impairment of HPT axis and consequently to a marked decrease of thyroid hormones levels as well as the levels of TRH and TSH. The latter abnormalities are not observed very often in diabetic patients. The treatment of rats with low-dose STZ induced the model of mild DM1. Characteristics of this model include moderate insulin deficiency and hyperglycemia [16,17], and rats with long-term mild DM1 had a less evident decrease in thyroid hormones levels and unchanged or elevated level of TSH, which is often observed in autoimmune thyroiditis combined with DM1 in humans $[15,18]$. The duration of mild DM1 in rats is at least 4-5 months, which is quite enough to study progressively developing changes of HPT axis. It is commonly accepted that insulin injections are the best way to treat DM1. However, in recent years, intranasal administration of insulin (I-I) has also found an application in the treatment of patients with DM and Alzheimer's disease, bipolar disorders, and some other neurological disorders [19-21]. Along with the action on the CNS, I-I via the central mechanisms controls biochemical and physiological processes in the periphery [21-23]. Regrettably, the influence of I-I on HPT axis and the thyroid gland has not been studied yet. This information is needed for the evaluation of therapeutic potential and adverse effects of long-term I-I treatment when it utilized in management of DM.

The aim of the present work was to study the influence of longterm I-I treatment on the function of HPT axis and the thyroid status in nondiabetic rats and in animals with the STZ models of acute and mild DM1. Long-term I-I treatment of diabetic rats restored thyroid hormones levels and sensitivity of HPT axis to TRH. The 135-day I-I treatment of rats with mild DM1 and respective control at a daily dose of $0.45 \mathrm{IU} /$ rat increased the serum TSH level significantly in comparison with untreated animals. Thus, this is the first study suggesting that long-term I-I treatment restores the function of HPT axis in DM1. It is also important that I-I induced a considerable increase in TSH levels in diabetic and nondiabetic animals, which should be taken into account when applying I-I to treat DM and nondiabetic neurological pathology.

\section{Materials and Methods}

$\nabla$

Animals

The male Wistar rats were housed in plastic sawdust-covered cages with a normal light-dark cycle. All experiments were carried out in agreement with the rules of the Bioethics Committee of Sechenov Institute of Evolutionary Physiology and Biochemistry, Russian Academy of Sciences, St. Petersburg, Russia (Institutional Guidelines, December 23, 2010) and according to the "Guide for the Care and Use of Laboratory Animals". Maximum effort was made to minimize animal suffering and to reduce the number of animals used. After a one-week adaptation period, rats aged 17-18 weeks were randomly divided into diabetic and control groups.

\section{Streptozotocin model of acute DM1 in rats}

The 30-day acute DM1 was induced by a single treatment of rats with STZ (Sigma, St. Louis, Mo, USA) dissolved in $0.1 \mathrm{M}$ citrate buffer ( $\mathrm{pH} 4.5$ ) at a dose of $60 \mathrm{mg} / \mathrm{kg}$. On the $3^{\text {rd }}$ day after treatment, plasma glucose levels in fasting rats were measured and the animals with glucose concentration over $26 \mathrm{mmol} / \mathrm{l}$ were considered diabetic and used in further experiments. Diabetic rats were subdivided into 4 groups, 3 of which were treated with I-I at the doses of 0.3 (acute- $\mathrm{D}_{2}+$ Ins $_{0.3}$ ), 0.6 (acute- $\mathrm{D}_{3}+\mathrm{Ins}_{0.6}$ ), and $1.5 \mathrm{IU}$ (acute- $\mathrm{D}_{4}+\mathrm{Ins}_{1.5}$ ) per rat, and one group received intranasally citrate buffer (acute- $\left.\mathrm{D}_{1}+\mathrm{Buf}\right)$. Control animals were also subdivided into 4 groups, one group received buffer $\left(\mathrm{C}_{1}+\mathrm{Buf}\right)$ and 3 groups were treated by I-I at 3 doses as described above $\left(C_{2}+\right.$ Ins $_{0.3}, C_{3}+$ Ins $_{0.6}$ and $C_{4}+$ Ins $\left._{1.5}\right)$ (Fig. 1S). The average body weight in the acute- $\mathrm{D}_{1}+$ Buf group was significantly reduced in comparison with control animals, while the plasma glucose level was 6 times higher. The treatment with I-I of control and diabetic rats led to a decrease of body weight in the acute- $\mathrm{D}_{4}+\mathrm{Ins}_{1.5}$ group ( $\mathrm{p}<0.05$ ), and to a decrease of plasma glucose level in the acute- $\mathrm{D}_{3}+\mathrm{Ins}_{0.6}$ group $(\mathrm{p}<0.01)$ (Table 1S). Significantly, on the $30^{\text {th }}$ day of experiment, the fasting insulinemia in the acute- $D_{1}+$ Buf group was $0.19 \pm 0.09 \mathrm{ng} / \mathrm{ml}$ and the treatment with I-I had little effect on it.

\section{Streptozotocin model of mild DM1 in rats}

Long-term mild DM1 was induced by 3 consecutive intraperitoneal injections of STZ dissolved in $0.1 \mathrm{M}$ citrate buffer $(\mathrm{pH} 4.5)$ at a dose of $30 \mathrm{mg} / \mathrm{kg}$ on the $1^{\text {st }}, 10^{\text {th }}$, and $80^{\text {th }}$ day of experiment. Nine days after the first and the second STZ treatment, plasma glucose levels in fasting rats were measured, and the animals with glucose concentration over $11 \mathrm{mmol} / \mathrm{l}$ were considered diabetic and used in the study. On the $75^{\text {th }}$ day diabetic rats were divided into 2 groups, one (mild- $\mathrm{D}_{2}+\mathrm{Ins}_{0.45}$ ) treated with I-I at a daily dose of $0.45 \mathrm{IU} /$ rat and the other with citrate buffer (mild$\mathrm{D}_{1}+\mathrm{Buf}$ ). Control animals were also divided into 2 groups. One group received I-I at a daily dose of $0.45 \mathrm{IU} / \mathrm{rat}\left(\mathrm{C}_{6}+\mathrm{Ins}_{0.45}\right)$, and the other received buffer without the hormone $\left(C_{5}+B u f\right)$ (Fig. 1S). Body weight of diabetic rats on the $150^{\text {th }}$ and $210^{\text {th }}$ day of experiment was lower compared with that of control animals, and after I-I treatment the body weight increased significantly, but remained below that of the rats in the $C_{5}+$ Buf and $C_{6}+$ Ins $_{0.45}$ groups. Plasma glucose level was significantly elevated in the mild- $\mathrm{D}_{1}+$ Buf group, and on the $150^{\text {th }}$ and $210^{\text {th }}$ day in diabetic rats treated with I-I it decreased by 30 and $40 \%$, respectively, remaining, however, twice higher than in respective control (Table 1S). On the $210^{\text {th }}$ day the level of plasma insulin in the mild- $\mathrm{D}_{1}+$ Buf group was $0.56 \pm 0.17 \mathrm{ng} / \mathrm{ml}$, and I-I had no significant effect on it.

\section{Intranasal delivery of insulin}

Intranasal delivery of insulin to rat's brain was performed as described earlier [24]. Crystalline insulin (Sigma, St. Louis, Mo, USA) at concentrations $15,22.5,30$, and $75 \mathrm{IU} / \mathrm{ml}$ was dissolved in $0.1 \mathrm{M}$ citrate buffer, $\mathrm{pH} 4.5$, and delivered intranasally to diabetic and nondiabetic rats once a day. Each animal was placed in a supine position and an average of $10 \mu \mathrm{l}$ of insulin solution was administered in each nostril $(0.3,0.45,0.6$, and $1.5 \mathrm{IU})$. Control animals were given the same volume of buffer, $\mathrm{pH} 4.5$.

\section{Determination of glucose and insulin levels}

Glucose level was measured in the whole blood from the tail vein using a glucometer (Life Scan Johnson \& Johnson, Denmark) and test strips One Touch Ultra (USA). Insulin concentration in rat serum was determined using the Rat Insulin ELISA (Mercodia $A B$, Sweden). 
TSH and the thyroid hormones assay

Serum TSH level was measured with an ELISA kit in accordance with the manufacturer's instructions (Cusabio Biotech. Co., Ltd., Wuhan, China). Serum concentrations of free thyroxine $\left(\mathrm{fT}_{4}\right.$ ), total circulating thyroxine $\left(\mathrm{tT}_{4}\right)$, and total circulating triiodothyronine $\left(\mathrm{tT}_{3}\right)$ were estimated by ELISA, following the protocol provided by Immunotech Company (Russia). All measurements were carried out with an Anthos Absorbance Reader 2020 (Anthos Labtec Instruments, Austria). Whole blood was obtained from the tail vein under local (sc) anesthesia with $2 \%$ lidocaine $(2-4 \mathrm{mg} / \mathrm{kg})$.

\section{The TRH test}

The test was performed at the end of the experiment, on the $30^{\text {th }}$ day in the case of acute DM1, and on the $215^{\text {th }}$ day of mild DM1. TRH was dissolved in saline $(20 \mu \mathrm{l})$ and administered intranasally to rats at a dose of $300 \mu \mathrm{g} / \mathrm{kg}$. Control rats were given the same volume of saline. To measure the levels of TSH and thyroid hormones, blood samples were collected $10 \mathrm{~min}$ before and $2 \mathrm{~h}$ after the TRH application.

\section{Statistical analysis}

The animal groups were analyzed by mixed ANOVA, using 2 factors, that is, method of treatment (Treatment), as the betweengroup factor with 3 or 4 levels, including control group, and time from the starting point of experiment (Time), as the repeated measure within-group factor with 5 or 4 levels. Each dependent variable, that is, the levels of $\mathrm{fT}_{4}, \mathrm{tT}_{4}$, and $\mathrm{tT}_{3}$, were estimated. The normality of distribution for all interventions at all-time points was assessed by Shapiro-Wilk's test $(p<0.05)$. The homogeneity of variances was assessed by Levene's test $(p>0.05)$. The assumption of sphericity was estimated using Mauchly's test $(\mathrm{p}<0.05)$. When the latter indicated that the assumption of sphericity was violated, a correction (Greenhouse-Geisser epsilon) was made. This allowed for the interaction between 2 factors to be evaluated. When the interaction was statistically significant, the difference between the groups was assessed at each level of Time, and the main simple effects were evaluated. At the final stage, post-hoc multiple comparisons were performed (Tukey) if one-way ANOVA showed a statistically significant difference between groups. If the interaction of factors was estimated as statistically nonsignificant, the main effect of Treatment was evaluated and the difference between groups was assessed according to this effect. The difference between groups of rats was assessed statistically using the one-way ANOVA ( $t$-test) and considered significant at $\mathrm{p}<0.05$. The data are presented as the mean $\pm \mathrm{SD}$.

\section{Results}

$\nabla$

The levels of thyroid hormones and TSH in rats with acute DM1 and their changes under the TRH treatment On the $15^{\text {th }}$ and $30^{\text {th }}$ day of the experiment, $\mathrm{fT}_{4}$ level in rats with acute DM1 decreased by 35 and $43 \%, \mathrm{tT}_{4}$ level by 15 and $20 \%$, and $\mathrm{tT}_{3}$ level by 22 and $39 \%$, respectively, and the changes were significant $(p<0.05)$ ( $\odot$ Table 1). Plasma concentration of TSH also decreased, but not significantly, and on the $15^{\text {th }}$ and $30^{\text {th }}$ day it was 80 and $57 \%$ of that before DM1 induction ( $\odot$ Table 1 ). A single treatment of the acute- $D_{1}+$ Buf rats (on the $30^{\text {th }}$ day of experiment) with intranasal TRH $(300 \mu \mathrm{g} / \mathrm{kg})$ induced an increase of
TSH concentration that was $60 \%$ of the $\mathrm{C}_{1}+$ Buf group increase. In diabetic rats, the TRH-induced increase of $\mathrm{fT}_{4}, \mathrm{tT}_{4}$, and $\mathrm{tT}_{3}$ levels was reduced by 51,28 , and $46 \%$, respectively, compared with that of the control, and for $\mathrm{fT}_{4}$ and $\mathrm{tT}_{3}$ the changes were significant $(p<0.05)(\boldsymbol{\theta}$ Fig. $\mathbf{1})$. These data indicate that in the 30-day acute DM1 the function of the HPT axis was reduced, and this led to a decline of thyroid hormones levels and a weaker response of pituitary thyrotrophs to TRH.

The effect of the 28-day I-I treatment on the levels of thyroid hormones and TSH and on the sensitivity of the HPT axis to TRH in nondiabetic and diabetic rats

The treatment of nondiabetic rats with I-I at the daily doses of 0.3 and $0.6 \mathrm{IU} / \mathrm{rat}$ induced a significant increase in thyroxine levels, but the effect was not present at the dose of $1.5 \mathrm{IU} / \mathrm{rat}$ ( 0 Table 1). Both the 13- and 28-day treatment with I-I at a dose of $0.3 \mathrm{IU} /$ rat increased TSH concentration by 74 and $63 \%$, but the difference was not statistically significant. In the $C_{3}+\operatorname{Ins}_{0.6}$ group, the stimulating effect of I-I on the TSH level was less pronounced. Sensitivity to TRH in the $C_{2}$ Ins $_{0.3}$ and $C_{3}+\operatorname{Ins}_{0.6}$ groups did not differ significantly from that of untreated animals. In the $\mathrm{C}_{4}+\mathrm{Ins}_{1.5}$ group the TRH-induced increase of the $\mathrm{tT}_{3}$ level decreased significantly in comparison with the $C_{1}+$ Buf group (० Fig. 1).

The 28-day treatment of diabetic animals with I-I at a dose of $0.6 \mathrm{IU} / \mathrm{rat}$ resulted in a partial restoration of the thyroid hormones levels. On the $30^{\text {th }}$ day the levels of $\mathrm{fT}_{4}, \mathrm{tT}_{4}$, and $\mathrm{tT}_{3}$ in the acute- $\mathrm{D}_{3}+$ Ins $_{0.6}$ group were increased by 38,15 , and $50 \%$ as compared to the untreated diabetic rats ( $\Theta$ Table 1 ). At a dose of $0.3 \mathrm{IU} / \mathrm{rat}$, the I-I did not influence the thyroid hormones levels in diabetic animals and at a dose of $1.5 \mathrm{IU} / \mathrm{rat}$, the I-I restored the $\mathrm{tT}_{3}$ level only. The 13-day treatment of diabetic rats with I-I at the doses of 0.6 and $1.5 \mathrm{IU} /$ rat resulted in an increase of the TSH concentration by 63 and $51 \%$, and the 28-day treatment gave an increase by 100 and $124 \%$, but the differences were not significant ( $\bullet$ Table 1$)$.

The stimulating influence of TRH on the levels of thyroid hormones and TSH in I-I-treated diabetic rats was more pronounced in comparison with the acute- $\mathrm{D}_{1}+$ Buf group. In the acute$\mathrm{D}_{3}+\mathrm{Ins}_{0.6}$ and acute- $\mathrm{D}_{4}+\operatorname{Ins}_{1.5}$ groups, the TRH-induced increase of the $\mathrm{fT}_{4}$ concentration was 87 and $94 \%$, and the increase of the $\mathrm{tT}_{3}$ concentration was 86 and $43 \%$ higher than in the diabetic rats without I-I treatment $(\mathrm{p}<0.05)(\boldsymbol{\odot}$ Fig. $\mathbf{1})$.

\section{The levels of thyroid hormones and TSH in rats with long-term mild DM1 and the influence of the I-I treatment}

On the $150^{\text {th }}$ day after the first STZ treatment, the plasma levels of $\mathrm{fT}_{4}$ and $\mathrm{tT}_{4}$ in rats with long-term mild DM1 had significantly decreased. On the $210^{\text {th }}$ day, the $\mathrm{fT}_{4}, \mathrm{tT}_{4}$, and $\mathrm{tT}_{3}$ levels decreased by 20,19 , and $33 \%$, and the changes were significant $(p<0.05)$ ( $\odot$ Table 2). The changes in thyroid hormones levels were quantitatively similar to those in acute DM1. Meanwhile, in longterm DM1 the plasma TSH level was significantly increased, while in acute DM1 it showed a trend to decrease. On the $210^{\text {th }}$ day the TSH level in the mild- $\mathrm{D}_{1}+$ Buf group was twice that of the respective control $(\mathrm{p}<0.05)$ ( $\bullet$ Table 2$)$. These data are evidences for decrease in thyroid sensitivity to TSH in long-term mild DM1.

The treatment of nondiabetic rats with the I-I at a daily dose of $0.45 \mathrm{IU} / \mathrm{rat}$ led to a notable increase of the plasma TSH level, 


\begin{tabular}{|c|c|c|c|}
\hline \multirow[t]{2}{*}{ Animal group } & \multicolumn{3}{|c|}{ Concentration of hormone, mean \pm SD } \\
\hline & $\begin{array}{l}\text { Prior to the experiment, } \\
0 \text { day }\end{array}$ & $15^{\text {th }}$ day & $30^{\text {th }}$ day \\
\hline \multicolumn{4}{|l|}{ Level of $\mathrm{fT}_{4}(\mathrm{pmol} / \mathrm{l})$} \\
\hline$C_{1}+\operatorname{Buf}(n=6)$ & $20.2 \pm 1.4$ & $19.5 \pm 2.0$ & $21.0 \pm 1.9$ \\
\hline$C_{2}+\ln s_{0.3}(n=6)$ & $20.9 \pm 1.9$ & $23.4 \pm 2.3^{+}$ & $25.8 \pm 3.1^{++}$ \\
\hline$C_{3}+\ln s_{0.6}(n=6)$ & $21.3 \pm 1.4$ & $24.7 \pm 2.1^{++}$ & $22.5 \pm 1.7$ \\
\hline$C_{4}+\operatorname{lns} 1.5(n=6)$ & $19.8 \pm 1.8$ & $21.5 \pm 1.2$ & $19.2 \pm 1.5$ \\
\hline acute- $D_{1}+\operatorname{Buf}(n=12,10,9)^{a}$ & $20.8 \pm 1.3$ & $13.6 \pm 2.7^{* *}$ & $11.9 \pm 2.5^{* *}$ \\
\hline acute- $\mathrm{D}_{2}+\operatorname{lns} \mathrm{s}_{0.3}(\mathrm{n}=6)$ & $20.1 \pm 1.3$ & $12.6 \pm 2.0$ & $12.5 \pm 1.0$ \\
\hline acute- $\mathrm{D}_{3}+\operatorname{lns} \mathrm{s}_{0.6}(\mathrm{n}=6)$ & $19.7 \pm 2.0$ & $15.1 \pm 3.2$ & $16.4 \pm 3.0^{++}$ \\
\hline acute- $D_{4}+\operatorname{lns}_{1.5}(n=6,6,5)^{b}$ & $20.7 \pm 0.9$ & $16.0 \pm 2.5$ & $14.6 \pm 1.5$ \\
\hline \multicolumn{4}{|l|}{ Level of tT4 (nmol/l) } \\
\hline$C_{1}+\operatorname{Buf}(n=6)$ & $70.9 \pm 3.4$ & $71.3 \pm 3.4$ & $72.9 \pm 4.2$ \\
\hline$C_{2}+\operatorname{lns} s_{0.3}(n=6)$ & $69.6 \pm 3.9$ & $81.8 \pm 4.4^{++}$ & $84.3 \pm 3.9^{++}$ \\
\hline$C_{3}+\operatorname{lns}_{0.6}(n=6)$ & $70.3 \pm 4.3$ & $83.3 \pm 4.5^{++}$ & $78.5 \pm 4.0$ \\
\hline$C_{4}+\operatorname{lns}_{1.5}(n=6)$ & $68.0 \pm 3.6$ & $78.2 \pm 4.0^{+}$ & $70.8 \pm 3.6$ \\
\hline acute- $D_{1+}$ Buf $(n=12,10,9)^{a}$ & $72.3 \pm 4.2$ & $61.8 \pm 5.0^{* *}$ & $58.2 \pm 4.6^{* *}$ \\
\hline acute- $\mathrm{D}_{2}+\operatorname{lns} \mathrm{s}_{0.3}(\mathrm{n}=6)$ & $69.7 \pm 4.8$ & $59.7 \pm 6.1$ & $62.5 \pm 3.7$ \\
\hline acute- $\mathrm{D}_{3}+\operatorname{lns}_{0.6}(\mathrm{n}=6)$ & $69.1 \pm 5.0$ & $63.2 \pm 9.2$ & $66.7 \pm 5.4^{++}$ \\
\hline acute- $D_{4}+\operatorname{lns}_{1.5}(n=6,6,5)^{b}$ & $69.6 \pm 2.1$ & $65.7 \pm 3.8$ & $64.1 \pm 3.6$ \\
\hline \multicolumn{4}{|l|}{ Level of $\mathrm{tT}_{3}(\mathrm{nmol} / \mathrm{l})$} \\
\hline$C_{1}+\operatorname{Buf}(n=6)$ & $2.2 \pm 0.2$ & $2.3 \pm 0.2$ & $2.4 \pm 0.3$ \\
\hline$C_{2}+\ln s_{0.3}(n=6)$ & $2.3 \pm 0.3$ & $2.6 \pm 0.2$ & $2.5 \pm 0.2$ \\
\hline$C_{3}+\ln s_{0.6}(n=6)$ & $2.1 \pm 0.3$ & $2.5 \pm 0.3$ & $2.5 \pm 0.4$ \\
\hline$C_{4}+\operatorname{lns} 1.5(n=6)$ & $2.2 \pm 0.3$ & $2.6 \pm 0.4$ & $2.7 \pm 0.3$ \\
\hline acute- $D_{1}+\operatorname{Buf}(n=12,10,9)^{a}$ & $2.3 \pm 0.3$ & $1.8 \pm 0.3^{* *}$ & $1.4 \pm 0.3^{* *}$ \\
\hline acute- $\mathrm{D}_{2}+\operatorname{lns} 0.3(\mathrm{n}=6)$ & $2.2 \pm 0.2$ & $1.9 \pm 0.3$ & $1.8 \pm 0.2$ \\
\hline acute- $\mathrm{D}_{3}+\ln \mathrm{s}_{0.6}(\mathrm{n}=6)$ & $2.2 \pm 0.2$ & $2.2 \pm 0.3$ & $2.1 \pm 0.3^{++}$ \\
\hline acute- $D_{4}+\operatorname{lns}_{1.5}(n=6,6,5)^{b}$ & $2.3 \pm 0.3$ & $2.4 \pm 0.3^{+}$ & $2.1 \pm 0.2^{++}$ \\
\hline \multicolumn{4}{|l|}{ Level of TSH $(\mu \mathrm{Ul} / \mathrm{ml})$} \\
\hline$C_{1}+\operatorname{Buf}(n=6)$ & $0.42 \pm 0.18$ & $0.40 \pm 0.17$ & $0.43 \pm 0.21$ \\
\hline$C_{2}+\ln s_{0.3}(n=6)$ & $0.43 \pm 0.18$ & $0.75 \pm 0.29$ & $0.70 \pm 0.19$ \\
\hline$C_{3}+\operatorname{lns}_{0.6}(n=6)$ & $0.38 \pm 0.16$ & $0.70 \pm 0.28$ & $0.58 \pm 0.32$ \\
\hline$C_{4}+\operatorname{lns} s_{1.5}(n=6)$ & $0.44 \pm 0.21$ & $0.49 \pm 0.33$ & $0.33 \pm 0.16$ \\
\hline acute- $D_{1}+\operatorname{Buf}(n=12,10,9)^{a}$ & $0.44 \pm 0.19$ & $0.35 \pm 0.15$ & $0.25 \pm 0.16$ \\
\hline acute- $\mathrm{D}_{2}+\operatorname{lns} 0.3(\mathrm{n}=6)$ & $0.39 \pm 0.11$ & $0.47 \pm 0.16$ & $0.35 \pm 0.17$ \\
\hline acute- $\mathrm{D}_{3}+\operatorname{lns} \mathrm{s}_{0.6}(\mathrm{n}=6)$ & $0.45 \pm 0.23$ & $0.57 \pm 0.18$ & $0.50 \pm 0.26$ \\
\hline acute- $D_{4}+\operatorname{lns}_{1.5}(n=6,6,5)^{b}$ & $0.41 \pm 0.09$ & $0.53 \pm 0.25$ & $0.56 \pm 0.33$ \\
\hline \multicolumn{4}{|l|}{ Values are the mean $\pm S D$} \\
\hline \multicolumn{4}{|c|}{$\begin{array}{l}{ }^{*} \text { and }{ }^{* *} \text { Statistically significant difference between } C_{1}+\text { Buf and acute- } D_{1}+\text { Buf groups at } p<0.05 \text { and } p<0.001 \\
{ }^{+} \text {and }{ }^{++} \text {Statistically significant difference between } C_{1}+\text { Buf and } C_{2-4}+\ln s_{0.3-1.5} \text { groups and between } D_{1}+\text { Buf and acute- } D_{2-4}+\ln s_{0.3-1.5} \\
\text { groups at } p<0.05 \text { and } p<0.001\end{array}$} \\
\hline
\end{tabular}

Table 1 The influence of treatment with I-I on the levels of $\mathrm{fT}_{4}, \mathrm{tT}_{4}, \mathrm{tT}_{3}$, and $\mathrm{TSH}$ in rats with acute DM1. while thyroid hormones level did not change significantly. The 75- and 135-day I-I treatment of diabetic rats increased significantly the plasma levels of thyroxine and TSH in comparison with the mild- $\mathrm{D}_{1}+$ Buf group. Furthermore, on the $150^{\text {th }}$ and $210^{\text {th }}$ day, the TSH level in the mild- $\mathrm{D}_{2}+$ Ins $_{0.45}$ group, when compared to the $C_{5}+$ Buf group, was 135 and $197 \%$ higher ( $\odot$ Table 2 ).

\section{The TRH test in rats with 210-day mild DM1 treated and untreated with I-I}

The increase of thyroid hormones level induced by a single application of intranasal TRH $(300 \mu \mathrm{g} / \mathrm{kg})$ in the mild $-\mathrm{D}_{1}+$ Buf group was less pronounced than in respective control. The TRHinduced increase of $\mathrm{fT}_{4}, \mathrm{tT}_{4}$, and $\mathrm{tT}_{3}$ levels in the mild- $\mathrm{D}_{1}+\mathrm{Buf}$ group amounted to 45,56 , and $67 \%$ of those in the $C_{5}+$ Buf group ( $\bullet$ Fig. 2). The TRH-induced increase of the TSH concentration in diabetic rats was twice lower than in the control animals. The 135-day treatment of diabetic animals with I-I led to an increase of the stimulating effects of TRH. In the mild- $\mathrm{D}_{2}+\mathrm{Ins}_{0.45}$ group the TRH-induced increase of plasma TSH level was 73\% higher and that of $\mathrm{fT}_{4}$ and $\mathrm{tT}_{4}$ levels 166 and $115 \%$ higher that of the mild- $\mathrm{D}_{1}+$ Buf group. However, the increase of $\mathrm{tT}_{3}$ concentration in the mild- $\mathrm{D}_{2}+\mathrm{InS}_{0.45}$ group remained at a low level, indicating a weakening of the $T_{4}$ to $T_{3}$ conversion. It follows that the longterm I-I treatment of the rats with mild DM1 ameliorated the function of the HPT axis and restored its sensitivity to TRH. In the $\mathrm{C}_{6}+$ Ins $_{0.45}$ group, the I-I did not change the TRH effect on the thyroxine and TSH levels, but led to a significant decrease of the $\mathrm{TRH}$-induced increase of the $\mathrm{tT}_{3}$ level.

\section{Discussion and Conclusions}

We have shown that the levels of $\mathrm{T}_{4}$ and $\mathrm{T}_{3}$ in rats with 30-day acute DM1 and with 210-day mild DM1 were decreased. This suggests changes in the synthesis of thyroid hormones and the decrease of the HPT axis response to the TRH. These data are in 


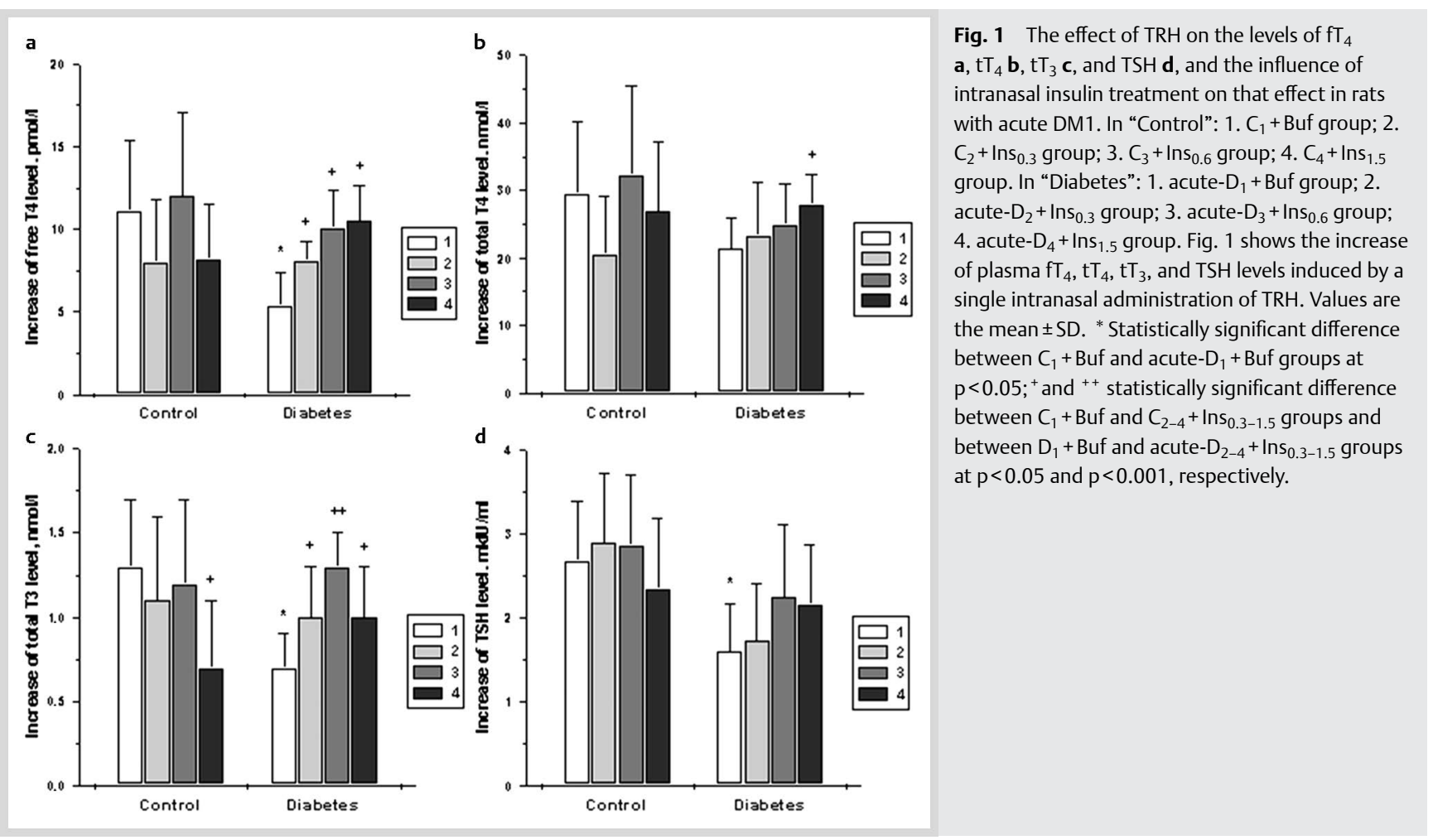

\begin{tabular}{|c|c|c|c|c|}
\hline Animal group & $\mathrm{fT}_{4}(\mathrm{pmol} / \mathrm{l})$ & $\mathrm{tT}_{4}(\mathrm{nmol} / \mathrm{l})$ & $\mathrm{tT}_{3}(\mathrm{nmol} / \mathrm{l})$ & TSH ( $\mu \mathrm{UI} / \mathrm{ml})$ \\
\hline \multicolumn{5}{|c|}{150 days after the first STZ treatment (75-day treatment with I-I) } \\
\hline$C_{5}+\operatorname{Buf}(n=6)$ & $20.7 \pm 1.8$ & $71.5 \pm 7.1$ & $2.1 \pm 0.4$ & $0.34 \pm 0.14$ \\
\hline$C_{6}+\operatorname{lns} s_{0.45}(n=6)$ & $18.7 \pm 1.7$ & $68.8 \pm 6.4$ & $2.1 \pm 0.4$ & $0.50 \pm 0.18^{+}$ \\
\hline mild $-D_{1}+B u f(n=10)^{a}$ & $13.8 \pm 3.5^{* *}$ & $59.3 \pm 8.8^{*}$ & $1.7 \pm 0.3$ & $0.52 \pm 0.21^{*}$ \\
\hline mild- $\mathrm{D}_{2}+\operatorname{lns}_{0.45}(\mathrm{n}=8)$ & $16.6 \pm 2.2^{+}$ & $65.7 \pm 5.5^{+}$ & $1.9 \pm 0.2$ & $0.80 \pm 0.26^{+}$ \\
\hline \multicolumn{5}{|c|}{210 days after the first STZ treatment (135-day treatment with I-I) } \\
\hline$C_{5}+\operatorname{Buf}(n=6)$ & $21.0 \pm 1.5$ & $73.9 \pm 5.9$ & $2.1 \pm 0.3$ & $0.35 \pm 0.13$ \\
\hline$C_{6}+\operatorname{lns}_{0.45}(n=6)$ & $20.8 \pm 1.5$ & $69.5 \pm 4.1$ & $1.8 \pm 0.2$ & $0.69 \pm 0.28^{+}$ \\
\hline mild- $D_{1}+$ Buf $(n=9)^{a}$ & $16.8 \pm 1.9^{* *}$ & $59.9 \pm 3.8^{*}$ & $1.4 \pm 0.2 * *$ & $0.71 \pm 0.23 *$ \\
\hline mild $-\mathrm{D}_{2}+\operatorname{lns} \mathrm{s}_{0.45}(\mathrm{n}=8)$ & $20.1 \pm 2.5^{+}$ & $68.0 \pm 6.8^{+}$ & $1.7 \pm 0.3$ & $1.04 \pm 0.29^{+}$ \\
\hline \multicolumn{5}{|l|}{ Values are the mean $\pm S D$} \\
\hline \multicolumn{5}{|c|}{$*$ and ${ }^{* *}$ Statistically significant difference between $C_{5}+$ Buf and mild- $D_{1}+$ Buf groups at $p<0.05$ and $p<0.001$} \\
\hline
\end{tabular}

good agreement with the results obtained by the other authors concerning functional disturbances in the HPT axis in experimental DM1 [11-15,25]. Of note is the fact that most studies were carried out on rats with acute DM1 induced by a high dose of STZ (55-75 mg/kg), which is characterized by absolute insulin deficiency, severe hyperglycemia and intoxication, typical of this model. These factors lead to pronounced dysfunctions of the HPT axis and to significant decrease in the levels of thyroid hormones and TSH, which allows to distinguish between experimental acute DM1 and human DM1, because, typically, there is no rapid and substantial reduction of thyroid hormones level in diabetic patients, and TSH level is maintained unchanged or increased [26].

This can be illustrated by the following experimental data. Three days after treatment with high-dose STZ, the Sprague-Dawley rats had significantly reduced plasma levels of $\mathrm{T}_{4}$ and $\mathrm{T}_{3}$ and a decreased level of circulating TRH [11]. These data indicate a simultaneous weakening of the secretory function of the thyroid follicular cells and the TRH-secreting hypothalamic neurons. Six and 15 days after STZ treatment, the $\mathrm{fT}_{4}$ level in Dutch-Miranda rats was decreased by 39 and $32 \%$ [15]. Two weeks after the STZ treatment of Wistar rats their thyroid hormones levels also decreased significantly and TRH secretion by the hypothalamic neurons was reduced to a large extent [13]. Alternatively, rapid changes in the HPT axis of human patients were only observed in aggressive DM1 in children with severe hyperglycemia and ketoacidosis, characteristic for this form of disease. The concentrations of $\mathrm{fT}_{4}, \mathrm{tT}_{4}$, and $\mathrm{tT}_{3}$ in these patients were reduced significantly within the first 3 days after they were diagnosed with DM1 [27]. In the long-term model of mild DM1 used in our study, the decrease of the $\mathrm{fT}_{4}$ level was less pronounced, which is more in line with the thyroid dysfunction rate in diabetic patients $[7,8]$. Findings presented in this study are consistent with the results of other authors who investigated thyroid function of Dutch-Miranda rats with 6-month DM1 induced by middle-dose of STZ (45 mg/kg) [15]. 

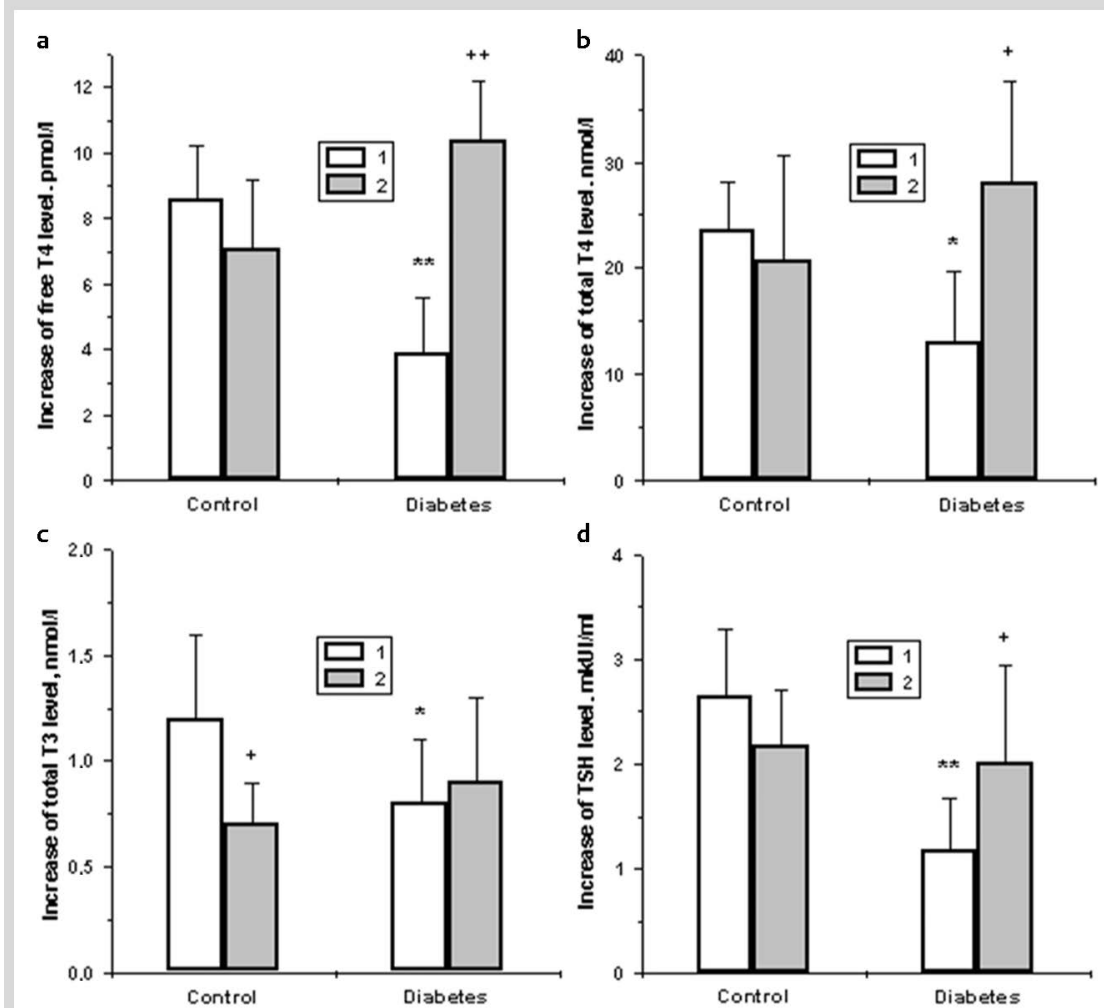

Fig. 2 The effect of TRH on the levels of $\mathrm{fT}_{4} \mathrm{a}, \mathrm{tT}_{4}$ b, $\mathrm{tT}_{3} \mathbf{c}$, and TSH d, and the influence of intranasal insulin treatment on that effect in rats with mild DM1. In "Control": 1. $C_{5}+$ Buf group; 2. $C_{6}+$ Ins $_{0.45}$ group; and in "Diabetes": 1. mild- $\mathrm{D}_{1}+$ Buf group; 2. mild- $D_{2}+\operatorname{lns}_{0.45}$ group. Fig. 2 shows the increase of plasma $\mathrm{fT}_{4}, \mathrm{tT}_{4}, \mathrm{tT}_{3}$, and TSH levels induced by a single intranasal administration of TRH on the $215^{\text {th }}$ day of experiment. Values are the mean \pm SD. ${ }^{*}$ and ${ }^{* *}$ Statistically significant difference between $C_{5}+$ Buf and mild- $D_{1}+$ Buf groups at $p<0.05$ and $p<0.001$; $^{+}$and ${ }^{++}$statistically significant difference between $\mathrm{C}_{5}+$ Buf and $\mathrm{C}_{6}+\operatorname{Ins}_{0.45}$ groups and between mild- $\mathrm{D}_{1}+$ Buf and mild- $\mathrm{D}_{2}+\operatorname{Ins}_{0.45}$ groups at $\mathrm{p}<0.05$ and $\mathrm{p}<0.001$, respectively.

Many researchers share the view that one of the main causes of decreased concentration of thyroid hormones at the early stages of acute DM1 is the decrease of TSH level due to the weakening of TSH secretion by pituitary thyrotrophs $[13,28]$. The TSH decrease can be ascribed to abnormalities in TRH-secreting hypothalamic neurons, lowering of sensitivity of the thyrotrophs to TRH, alterations in activity of the type 25 -deiodinase in the pituitary and the hypothalamus, reduced expression of TSH gene, and other causes [12,13,29-31]. In Sprague-Dawley rats, 3 days after the DM1 induction, and in Wistar rats, 2 weeks after the STZ treatment, TSH level was significantly reduced $[11,13]$. The results of our experiments on rats with acute DM1 are consistent with these findings by other authors. A reduced production of thyroid hormones may be the result of thyroid cells' resistance to TSH [12,32,33], which is due, primarily, to the weakening of TSH receptor sensitivity to TSH in thyrocytes and the changes in TSH-regulated intracellular signaling cascades. Earlier we have shown that in the thyroid gland of rats with acute DM1 the TSH-induced stimulation of adenylate cyclase activity was reduced $[18,34]$. Additionally, a decrease of sensitivity of the pituitary gland to TRH, indicated by the reduction of TRH-induced increase of the TSH level in the acute- $\mathrm{D}_{1}+\mathrm{Buf}$ group, can contribute to the decrease of thyroid hormones levels in DM1.

When the STZ dose is decreased, the TSH level does not change significantly or even increased, while the levels of thyroid hormones stay lowered. Similar data was obtained by other researchers in the study of female Dutch-Miranda rats with long-term mild DM1 (6 months) [15]. According to our results, 7 months after the DM induction, TSH concentration in diabetic rats was twice that of the control animals, while the response of the pituitary to TRH was attenuated. Combination of thyroid hormones deficiency and normal or elevated TSH level points to the development of a hypothyroid state in rats with mild DM1. Our data are in good agreement with the clinical reports when hypothyroidism is observed in diabetic patients. These patients frequently have autoimmune thyroiditis with an elevated TSH level, and in some cases the increase of TSH level is significant $[7,35]$. Thus, for the evaluation of human DM1-associated thyroid disorders the mild DM1 model seems more suitable than the acute DM1 model.

Traditionally the treatment of DM1 is carried out by subcutaneous or intramuscular injections of insulin. This treatment normalizes the glucose level and improves the endocrine functions disturbed in hyperglycemia and insulin deficiency. This therapeutic effect of injected insulin can be recapitulated in experimental conditions to the HPT axis. The treatment of diabetic rats with parenterally administered insulin leads to partial restoration of the HPT axis function and the thyroid hormones levels [36-38]. Even relatively low dose of insulin (1.0 IU/rat) partially restored the levels of $\mathrm{fT}_{4}, \mathrm{tT}_{4}$, and $\mathrm{tT}_{3}$ in diabetic rats, despite the fact that at this dose insulin did not result in normalized glucose levels [37]. The effectiveness of low doses of insulin for restoration of the HPT axis in acute DM1 shows a high sensitivity of its components, primarily the TRH-secreting hypothalamic neurons, to insulin. This suggestion is supported by the evidence that treatment of hypothalamic neurons obtained from diabetic animals with low-dose insulin results in a significant increase of TRH secretion [39].

As early as 1995, a hypothesis was put forward that brain insulin may increase the secretion of TRH due to suppression of the neuropeptide $\mathrm{Y}$ release by the paraventricular nuclei of hypothalamus [40]. Neuropeptide $\mathrm{Y}$ inhibits TRH secretion [41], while intracerebroventricular administration of insulin suppresses the expression of the neuropeptide $\mathrm{Y}$ gene [42]. TRH secretion is stimulated by leptin, acting either directly via leptin 
receptors located on the TRH-producing neurons or indirectly via activation of the brain melanocortin system, which increases $\alpha$-melanocyte-stimulating hormone release from the pro-opiomelanocortin neurons [43]. It is worth noting that brain insulin signaling system is involved in the interaction with the leptin and the melanocortin signaling systems, whereby insulin in CNS can influence their functional activity directly.

Another way that brain insulin can influence the functions of the thyroid system is through the somatostatin signaling system. Somatostatin is one of the most important regulators of the HPT axis, due to its suppression of TRH and TSH secretion $[44,45]$. There is evidence that in DM1 somatostatin level can be increased, as shown in human DM1 and in the gastrointestinal tract of nonobese diabetic mice [46-48], or can be unchanged or reduced, as demonstrated in rats with STZ-induced DM [49-51]. Since the somatostatin and the insulin signaling systems are functionally linked [52], the increase of insulin level in the brain can directly affect the somatostatin level and, thereby, modulate somatostatin effects on TSH production. It was also shown that the insulin-degrading enzyme, whose activity in the brain is increased due to the increase of insulin level, can hydrolyze somatostatin [53]. This leads to the decrease of brain somatostatin content and, as a result, can suppress the inhibitory effect of somatostatin on the secretion of TRH and TSH.

However, there are no reports that address the influence of centrally administered insulin on thyroid status of rats. One study describes the effect of insulin administered into the brain on the thyroid status of starving rats, but since levels of insulin, leptin, and glucose in these animals were significantly reduced, this could affect the regulation of the activity of TRH-producing hypothalamic neurons without and under the brain insulin action [54].

Importantly, the extent to which the function of the HPT axis and the thyroid status depend on brain insulin level is one of immediate problems for clinical and experimental endocrinology and neurology. It is of great importance for the development of new approaches to I-I-based treatment of neurodegenerative diseases and DM. The I-I is delivered directly into the brain, increasing its concentration in CNS and restoring functional activity of brain insulin signaling system in the cases of insulin deficiency (DM1) or insulin resistance (Alzheimer's disease, metabolic syndrome, DM2) [19,20].

As first demonstrated by this study, long-term (28 to 135 days) I-I treatment restores thyroid hormones levels decreased in DM1, and this effect is detected in both acute and mild DM1 model. The I-I treatment also leads to an increase of TRH sensitivity of the HPT axis, which is decreased in diabetic rats. The dependence on I-I doses used in present study was also investigated (see section "Results"). All this shows that in the case of absolute (acute DM1) or relative (mild DM1) insulin deficiency the increase of insulin concentration in the brain prevents or reduces the deficiency of thyroid hormones characteristic for DM1.

It is very important to note that our results suggest that hyperglycemia is not completely recovered after the I-I-treatment of diabetic rats. This gives grounds to say that hyperglycemia is not to be regarded as a key factor in determining the activity of the HPT axis in DM1. In nondiabetic rats, the I-I did not have a significant effect on the level of thyroid hormones, except for the stimulating effect of I-I on thyroxine level in the course of the 28-day treatment, suggesting a weak relationship between the activity of the brain insulin signaling system and thyroid hormones production in healthy, nonhypothyroid, animals.

The difference in the results depending on the doses of I-I is likely to be due to the fact that in the brain of diabetic rats there is a large insulin deficiency, which requires administration of higher doses of I-I to be compensated. In our opinion, the 30-day administration of high doses of I-I ( 0.6 and $1.5 \mathrm{IU} / \mathrm{rat})$ to nondiabetic animals could lead to desensitization of insulin receptors and development of insulin resistance in the brain, which explains the weakening of stimulating effect of I-I at these doses on the production of TSH and thyroxine on the $30^{\text {th }}$ day as compared to that on the $15^{\text {th }}$ day of experiment ( $\odot$ Table 1 ).

As demonstrated earlier by us, long-term treatment of rats with the prolonged model of mild DM1 or the neonatal model of DM2, using I-I at the daily doses of $0.45-0.48 \mathrm{IU} / \mathrm{rat}$, led to a partial restoration of activity of the brain adenylyl cyclase signaling system sensitive to monoamines and peptide hormones [24]. In our opinion, there are reasons to regard I-I-induced restoration of functional activity of the integrative network of the brain neurotransmitter systems in diabetic animals as one of the key factors responsible for an increase in sensitivity of the pituitary to TRH, enhanced synthesis and secretion of TSH by thyrotrophs and the restoration of HPT axis function. It should be pointed out that the restoration effect of I-I on the neurotransmitter systems (see above) was detected using the same doses and duration of treatment as in the case of stimulating influence of I-I on the HPT axis.

In summary, our data show that long-term I-I treatment of rats with the models of acute or mild DM1 leads to the improvement of their thyroid status; this manifests as the increase of the thyroid hormones levels and the restoration of the HPT axis sensitivity to TRH, both of which are reduced in DM1. In acute DM1, different doses of I-I (0.3-1.5 IU/rat) were used and a daily dose of $0.6 \mathrm{IU} / \mathrm{rat}$ appeared to be the most effective. The latter dose is close to dose of $0.45 \mathrm{IU} /$ rat that had strong positive effect in mild DM1. Based on our findings, it can be concluded that I-I treatment is a valid approach to correction of hypothyroid states in patients with DM1, but in the case of long-term treatment of rats with I-I when TSH level is significantly increased, it is necessary to control the hormonal status of the HPT axis, especially the level of TSH. Since one-month I-I treatment did not cause a noticeable increase of the TSH level and at the same time led to a partial restoration of thyroid hormone deficiency, the use of relatively short courses of I-I should be regarded as the most suitable method of clinical application. This also applies to patients with nondiabetic pathologies, Alzheimer's disease in particular. These recommendation are especially relevant in the latter case as the I-I treatment is now considered to be one of perspective way in Alzheimer's disease therapy $[19,55]$.

\section{Acknowledgements}

$\nabla$

This work was supported by the Russian Science Foundation (Project No 14-15-00413).

\section{Conflict of Interest}

$\checkmark$

The authors declare no conflict of interest. 
References

1 Zoeller RT, Tan SW, Tyl RW. General background on the hypothalamicpituitary-thyroid (HPT) axis. Crit Rev Toxicol 2007; 37: 11-53

2 Chakrabarti S. Thyroid functions and bipolar affective disorder. J Thyroid Res 2011; 2011: Article ID 306367, 13 Pages

3 Ertek S, Cicero AF. Hyperthyroidism and cardiovascular complications: a narrative review on the basis of pathophysiology. Arch Med Sci 2013; 9: 944-952

4 Sharma AK, Arya R, Mehta R, Sharma R, Sharma AK. Hypothyroidism and cardiovascular disease: factors, mechanism and future perspectives. Curr Med Chem 2013; 20: 4411-4418

5 Wood-Allum CA, Shaw PJ. Thyroid disease and the nervous system. In: Aminoff M, Boller F, Swaab D (eds.). Handbook of Clinical Neurology. Amsterdam: Elsevier, 2014; 120: 703-735

6 Dittmar M, Kahaly GJ. Genetics of the autoimmune polyglandular syndrome type 3 variant. Thyroid 2010; 20: 737-743

7 Kadiyala R, Peter R, Okosieme OE. Thyroid dysfunction in patients with diabetes: clinical implications and screening strategies. Int J Clin Pract 2010; 64: 1130-1139

8 Duntas LH, Orgiazzi J, Brabant G. The Interface between thyroid and diabetes mellitus. Clin Endocrinol (Oxf) 2011; 75: 1-9

9 Gray RS, Borsey DQ Seth J, Herd R, Brown NS, Clarke BF. Prevalence of subclinical thyroid failure in insulin-dependent diabetes. J Clin Endocrinol Metab 1980; 50: 1034-1037

10 Mouradian M, Abourizk N. Diabetes mellitus and thyroid disease. Diabetes Care 1983; 6: 512-520

11 Wilber JF, Banerii A, Prasad C, Mori M. Alterations in hypothalamicpituitary-thyroid regulation produced by diabetes mellitus. Life Sci 1981; 28: 1757-1763

12 Bestetti GE, Reymond MJ, Perrin IV, Kniel PC, Lemarchand-Béraud T, Rossi GL. Thyroid and pituitary secretory disorders in streptozotocindiabetic rats are associated with severe structural changes of these glands. Virchows Arch B Cell Pathol Incl Mol Pathol 1987; 53: 69-78

13 Rondeel JM, de Greef WJ, Heide R, Visser TJ. Hypothalamo-hypophysialthyroid axis in streptozotocin-induced diabetes. Endocrinology 1992; 130: $216-220$

14 van der Elst JPS, van der Heide D. Effects of streptozotocin-induced diabetes and food restriction on quantities and source of T4 and T3 in rat tissues. Diabetes 1992; 41: 147-152

15 Nascimento-Saba CC, Breitenbach MM, Rosenthal D. Pituitary-thyroid axis in short- and long-term experimental diabetes mellitus. Braz J Med Biol Res 1997; 30: 269-274

16 Shpakov A, Derkach K, Moyseyuk I, Chistyakova O. Alterations of hormone-sensitive adenylyl cyclase system in the tissues of rats with long-term streptozotocin diabetes and the influence of intranasal insulin. Dataset Papers Pharmacol 2013; 2013: 698435 http://dx.doi. org/10.7167/2013/698435

17 Shpakov AO, Derkach KV, Chistyakova OV, Moyseyk IV, Bondareva VM. The effect of long-term diabetes mellitus induced by treatment with streptozotocin in 6-week-old rats on functional activity of the adenylyl cyclase system. Cell Tis Biol 2014; 8: 68-79

18 Derkach K, Moyseyuk IV, Shpakov AO. The influence of prolonged streptozotocin diabetes on the thyroid gland function in rats. Dokl Biochem Biophys 2013; 451: 217-220

19 Freiherr J, Hallschmid M, Frey WH 2nd, Brünner YF, Chapman CD, Hölscher C, Craft S, De Felice FG, Benedict C. Intranasal insulin as a treatment for Alzheimer's disease: a review of basic research and clinical evidence. CNS Drugs 2013; 27: 505-514

20 McIntyre RS, Soczynska JK, Woldeyohannes HO, Miranda A, Vaccarino A, Macqueen G, Lewis GF, Kennedy SH. A randomized, double-blind, controlled trial evaluating the effect of intranasal insulin on neurocognitive function in euthymic patients with bipolar disorder. Bipolar Disord 2012; 14: 697-706

21 Blázquez E, Velázquez E, Hurtado-Carneiro V, Ruiz-Albusac JM. Insulin in the brain: its pathophysiological implications for States related with central insulin resistance, type 2 diabetes and Alzheimer's disease. Front Endocrinol (Lausanne) 2014; 5: 161

22 Benedict C, Kern W, Schultes B, Born J, Hallschmid M. Differential sensitivity of men and women to anorexigenic and memory-improving effects of intranasal insulin. J Clin Endocrinol Metab 2008; 93: 13391344

23 Ott V, Benedict C, Schultes B, Born J, Hallschmid M. Intranasal administration of insulin to the brain impacts cognitive function and peripheral metabolism. Diabetes Obes Metab 2012; 14: 214-221

24 Shpakov AO, Chistyakova OV, Derkach KV, Moiseyuk IV, Bondareva VM. Intranasal insulin affects adenylyl cyclase system in rat tissues in neonatal diabetes. Central Eur J Biol 2012; 7: 33-47
25 Saravanan G, Ponmurugan P. Antidiabetic effect of S-allylcysteine: effect on thyroid hormone and circulatory antioxidant system in experimental diabetic rats. J Diabetes Complicat 2012; 26: 280-285

26 Steger $R W$, Rabe $M B$. The effect of diabetes mellitus on endocrine and reproductive function. Proc Soc Exp Biol Med 1997; 214: 1-11

27 Lin CH, Lee YJ, Huang CY, Kao HA, Shih BF, Wang AM, Lo FS. Thyroid function in children with newly diagnosed type 1 diabetes mellitus. Acta Paediatr Taiwan 2003; 44: 145-149

28 Bestetti GE, Brändli P, Rossi GL. Secretory disorders in pituitary thyrotropes of streptozocin-diabetic male rats. Acta Anat (Basel) 1994; 149: 215-220

29 Rodríguez M, Rodríguez F, Jolin T, Santisteban P. Comparative effects of food restriction, fasting, diabetes and thyroidectomy on growth hormone and thyrotropin gene expression in the rat pituitary. Eur J Endocrinol 1995; 133: 110-116

30 Ortiga-Carvalho TM, Curty FH, Nascimento-Saba CC, Moura EG, Polak J, Pazos-Moura CC. Pituitary neuromedin B content in experimental fasting and diabetes mellitus and correlation with thyrotropin secretion. Metabolism 1997; 46: 149-153

31 Aláez C, Calvo R, Obregón MJ, Alvarez C, Goya L, Escrivá F, Martín MA Pascual-Leone AM. Influence of type II 5' deiodinase on TSH content in diabetic rats. J Physiol Biochem 2001; 57: 221-230

32 Liu C, Shu C. Morphological studies of the adrenal zona glomerulosa cells and the thyroid and pituitary glands in streptozocin-induced experimental diabetic rats. Zhonghua Bing Li Xue Za Zhi 1996; 25 : $358-360$

33 Nascimento-Saba CC, Brito AC, Pereira MJ, Carvalho JJ, Rosenthal D. Autoradiographic thyroid evaluation in short-term experimental diabetes mellitus. Braz J Med Biol Res 1998; 31: 299-302

34 Moiseyuk IV, Derkach KV, Shpakov AO. Functional activity of thyroid gland in male rats with acute and mild streptozotocin diabetes. J Evol Biochem Physiol 2014; 50: 310-320

35 Chase HP, Garg SK, Cockerham RS, Wilcox WD, Walravens PA. Thyroid hormone replacement and growth of children with subclinical hypothyroidism and diabetes. Diabet Med 1990; 7: 299-303

36 Ortiz-Caro J, González C, Jolin T. Diurnal variations of plasma growth hormone, thyrotropin, thyroxine, and triiodothyronine in streptozotocin-diabetic and food-restricted rats. Endocrinology 1984; 115: 2227-2232

37 Katovich MJ, Marks KS, Sninsky CA. Effect of insulin on the altered thyroid function and adrenergic responsiveness in the diabetic rat. Can J Physiol Pharmacol 1993; 71: 568-575

38 Santos MC, Louzada RA, Souza EC, Fortunato RS, Vasconcelos AL, Souza $K L$, Castro JP, Carvalho DP, Ferreira AC. Diabetes mellitus increases reactive oxygen species production in the thyroid of male rats. Endocrinology 2013; 154: 1361-1372

39 van Haasteren GA, Sleddens-Linkels E, van Toor H, Klootwijk $W$, de Jong FH, Visser TJ, de Greef WJ. Possible role of corticosterone in the down-regulation of the hypothalamo-hypophysial-thyroid axis in streptozotocin-induced diabetes mellitus in rats. J Endocrinol 1997; 153: 259-267

40 McCarty MF. Central insulin may up-regulate thyroid activity by suppressing neuropeptide $Y$ release in the paraventricular nucleus. Med Hypotheses 1995; 45: 193-199

41 Fekete C, Kelly J, Mihaly E, Sarkar S, Rand WM, Legradi G, Emerson $\mathrm{CH}$, Lechan RM. Neuropeptide Y has a central inhibitory action on the hypothalamic-pituitary-thyroid axis. Endocrinology 2001; 142: 2606-2613

42 Wang J, Leibowitz KL. Central insulin inhibits hypothalamic galanin and neuropeptide $\mathrm{Y}$ gene expression and peptide release in intact rats. Brain Res 1997; 777: 231-236

43 Nillni EA. Regulation of the hypothalamic thyrotropin releasing hormone (TRH) neuron by neuronal and peripheral inputs. Front Neuroendocrinol 2010; 31: 134-156

44 Skamene A, Patel YC. Infusion of graded concentrations of somatostatin in man: pharmacokinetics and differential inhibitory effects on pituitary and islet hormones. Clin Endocrinol (Oxf) 1984; 20: 555-564

45 Grimberg $A$. Somatostatin and cancer: applying endocrinology to oncology. Cancer Biol Ther 2004; 3: 731-733

46 Matsushima Y, Makino H, Kanatsuka A, Osegawa M, Kumagai A, Nishimura M, Tochino Y, Makino S. Pancreatic somatostatin contents in spontaneously diabetic KK and non-obese diabetic (NOD) mice. Horm Metab Res 1982; 14: 292-298

47 Orskov H, Flyvbjerg A, Frystyk J, Ledet T, Møller N, Christensen SE, Harris $A G$. Octreotide and diabetes: theoretical and experimental aspects. Metabolism 1992; 41: 66-71 
48 El-Salhy M, Spångéus A. Gastric emptying in animal models of human diabetes: correlation to blood glucose level and gut neuroendocrine peptide content. Ups J Med Sci 2002; 107: 89-99

49 Fernstrom JD, Fernstrom MH, Kwok RP. In vivo somatostatin, vasopressin, and oxytocin synthesis in diabetic rat hypothalamus. Am J Physiol 1990; 258: 661-666

50 Tang $F$, Wong $R P$. Pituitary contents of $\beta$-endorphin, dynorphin, substance P, cholecystokinin and somatostatin in rats with streptozotocin-induced diabetes. Biol Signals 1996; 5: 44-50

51 Szilvássy Z, Németh J, Kovács P, Paragh G, Sári R, Vígh L, Peitl B. Insulin resistance occurs in parallel with sensory neuropathy in streptozotocin-induced diabetes in rats: differential response to early vs late insulin supplementation. Metabolism 2012; 61: 776-786

52 Caruso MA, Sheridan MA. Differential regulation of the multiple insulin and insulin receptor mRNAs by somatostatin. Mol Cell Endocrinol 2014; 384: 126-133
53 Ciaccio C, Tundo GR, Grasso G, Spoto G, Marasco D, Ruvo M, Gioia M, Rizzarelli $E$, Coletta $M$. Somatostatin: a novel substrate and a modulator of insulin-degrading enzyme activity. J Mol Biol 2009; 385: 1556-1567

54 Fekete C, Singru PS, Sanchez E, Sarkar S, Christoffolete MA, Riberio RS, Rand WM, Emerson CH, Bianco AC, Lechan RM. Differential effects of central leptin, insulin, or glucose administration during fasting on the hypothalamic-pituitary-thyroid axis and feeding-related neurons in the arcuate nucleus. Endocrinology 2006; 147: 520-529

55 Alagiakrishnan K, Sankaralingam S, Ghosh M, Mereu L, Senior P. Antidiabetic drugs and their potential role in treating mild cognitive impairment and Alzheimer's disease. Discov Med 2013; 16: 277-286 